\title{
Ground support from a corporate perspective
}

\author{
M Board Hecla Ltd., USA
}

\begin{abstract}
This paper describes the role of the corporate ground control function within Hecla Ltd., a mid-tier US precious metals producer. The position of the ground control function within the corporate structure and the primary responsibility of evaluating and communicating geotechnical risk at company operations and during acquisition is emphasised. A case example is given of how the corporate ground control function was involved in recent ground support issues encountered during the sinking of a 3,000 m deep shaft at the Lucky Friday mine.
\end{abstract}

Keywords: corporate ground control, Lucky Friday mine

\section{Introduction}

"I'm from the corporate office - I'm here to help"

Although a universal joke, how many of us who have worked at mines-from ground control engineer to the general manager (GM)-have hoped that the head office staff would simply allow the mine to go about the hard work of making their operation safe and productive without intervention, particularly from people who rarely set foot underground. In this paper, I discuss what I see as the primary goal of corporate ground control engineering-assessment and communication of the general geotechnical risk at the mine operations-and how assistance can be given in setting standards for mine design, ground support methods and operational procedures used to mitigate this risk. Additionally, the corporate ground control function provides technical oversight and quality assurance, mentoring, and pushing of the organisation to seek new and innovative solutions to ground control. This paper provides a description of how the corporate ground control function is carried out within Hecla Mining Company, a US precious metals miner.

\section{$2 \quad$ Hecla Mining Company}

Hecla Mining Company is a mid-tier precious metals producer headquartered in Coeur d'Alene, Idaho, USA. The company, founded in 1891, is the oldest incorporated mining company and the largest silver producer in the USA. The company operates seven primary silver and gold mines in the USA, Canada and Mexico (Figure 1).

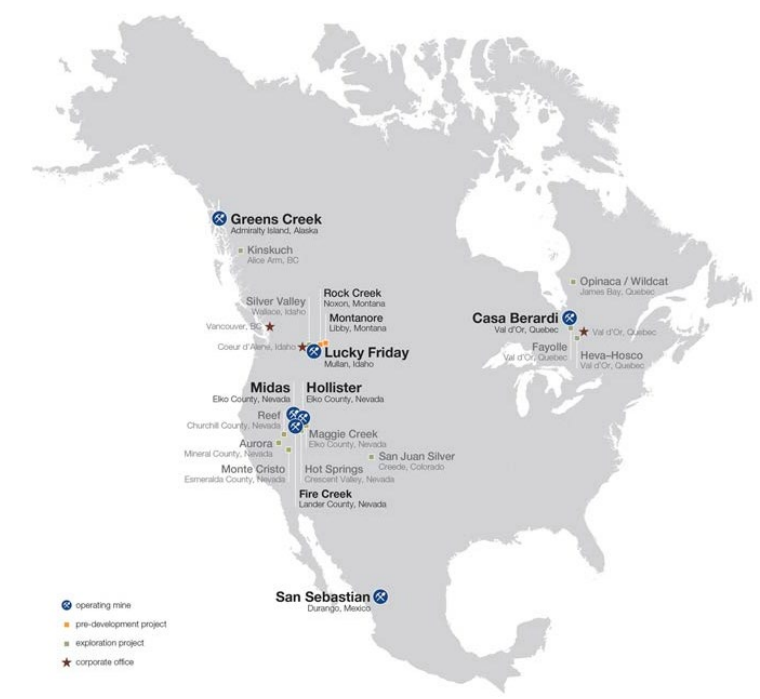

Figure 1 Hecla mines, pre-production and exploration projects 
The mines are primarily underground operations, although Casa Berardi in Quebec and San Sebastian in Mexico also operate open pits. The underground mines are primarily narrow-vein operations utilising a combination of longhole and cut-and-fill methods. A variety of challenging ground conditions are found in most of the operations, including high-stress conditions, large deformations and seismicity in the 78 year old Lucky Friday mine (Idaho, maximum depth $\sim 3,000 \mathrm{~m}$ ), graphitic faults and heavily foliated, weak sediments at Casa Berardi, highly altered, weak, water-sensitive and time-dependent deforming rocks in the Nevada operations, and corrosive ground conditions at the Greens Creek mine in Alaska.

\subsection{Evolution of geotechnical engineering in the corporate structure}

Prior to 2012, the rock engineering functions within the company resided within the technical services department at each mine site, reporting to the underground superintendent at that operation. In 2011, a series of unfortunate events occurred at the Lucky Friday mine, including a fatal ground fall as well as several damaging seismic events, resulting in a year-long shutdown of the mine operations. After these incidents, a re-evaluation of the way the company managed ground control and safety, in general, was conducted. These evaluations resulted in the hiring of a new company chief operating officer (COO) and corporate safety director as well as creation of the new position of corporate director of geotechnical engineering. The corporate geotechnical engineering function was later elevated to vice president (VP) status in the form of the vice president of technical services. Additionally, engineers with specific specialties and experience in mining rock mechanics were hired to assume positions as ground control engineer at each operation ${ }^{1}$. In the months that followed, a completely new risk-based corporate safety management system (CORE Safety programme from the US National Mining Association) was implemented at all operations as well as development of a uniform set of standards for how ground support is applied to day-to-day mine operations. The CORE Safety programme includes a standard risk assessment rating process which is incorporated into operational tasks and short- and long-term mine design. Risk assessments include a geotechnical component to provide a risk ranking that includes a probability and consequence estimate. Additionally, all mines have a similar set of requirements for the ground control management plans (GCMP) and how these plans are incorporated into the mine operations.

The current corporate structure is shown in Figure 2, illustrating that the geotechnical engineering function operates at the same level of authority as all mine site VP-general manager positions, reporting to the COO of the company. The geotechnical risk evaluation of every operation is reported to the board of directors at all quarterly board meetings. The status of the geotechnical engineering function within the corporate structure indicates the importance that Hecla upper management and board of directors places on the ground control function for the safety and productivity of its operations.

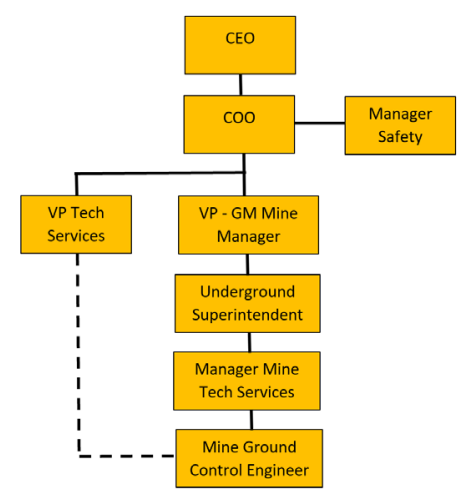

Figure 2 How ground control function reports in company organisation (VP tech services is also corporate geotechnical engineer)

1 Previously, the ground control engineer at any operation may have been a mining engineer or geologist who often assumed that role as part of their overall work. 


\subsection{Functions of the corporate geotechnical manager: ground support and related activities}

The following are the general responsibilities of the corporate geotechnical engineering function within Hecla:

- Communication, mine to corporate management: act as an interface between mine operations and corporate management on matters concerning ground control. This includes conveying an assessment of geotechnical risk for the mines in general, but also on all major projects and acquisitions. The risk assessment is presented on a quarterly basis to the board of directors.

- Safety and quality assurance: acting with mine management, safety and ground control engineers, work to ensure a safe working environment.

- Develop, approve and implement site GCMP in cooperation with site ground control engineer.

- Ensure that quality assurance functions for installation and testing of ground support, backfill, etc. are developed and implemented at each operation.

- Perform regular underground inspections, reporting results to the mine superintendent.

- Act as in-house consultant to operations: interact directly with site GMs as needed.

- Interact with government safety and enforcement agencies as required.

- Mine planning: review and assess geotechnical risk for short- and long-term mine planning at each operation. Ensure that ground control is incorporated into and has signature approval of all mine plans. Assist in development and implementation of new mining concepts as needed.

- Suppliers and research: company lead in development/implementation of new/innovative ground support methods.

- Regular dialogue with ground support suppliers, development and testing of new products and processes as needed.

- Interact with government mining research organisations (National Institute for Occupational Safety and Health in USA) in development and testing of new ground support methodologies.

○ Engagement with outside consultants as needed.

- Training: train/mentor site geotechnical engineers.

\section{Case example: ground support in a deep shaft at the Lucky Friday mine}

To illustrate how the corporate ground control function interacts with mine operations within Hecla, it is best to show a case example. Here, a discussion of the process of dealing with ground control issues encountered during the recent sinking of the deep \#4 Shaft at the Lucky Friday mine is given.

\subsection{Lucky Friday mine operations}

Lucky Friday is an $800 \mathrm{t} /$ day operation that uses an underhand cut-and-fill mining method with cemented paste backfill to extract silver, lead and zinc ore from several narrow, vertical veins. The primary vein extracted is 30 Vein, which strikes roughly east-west, has a mineable strike length of approximately $770 \mathrm{~m}$ and average stoping width of about $4 \mathrm{~m}$ (Figure 3). 


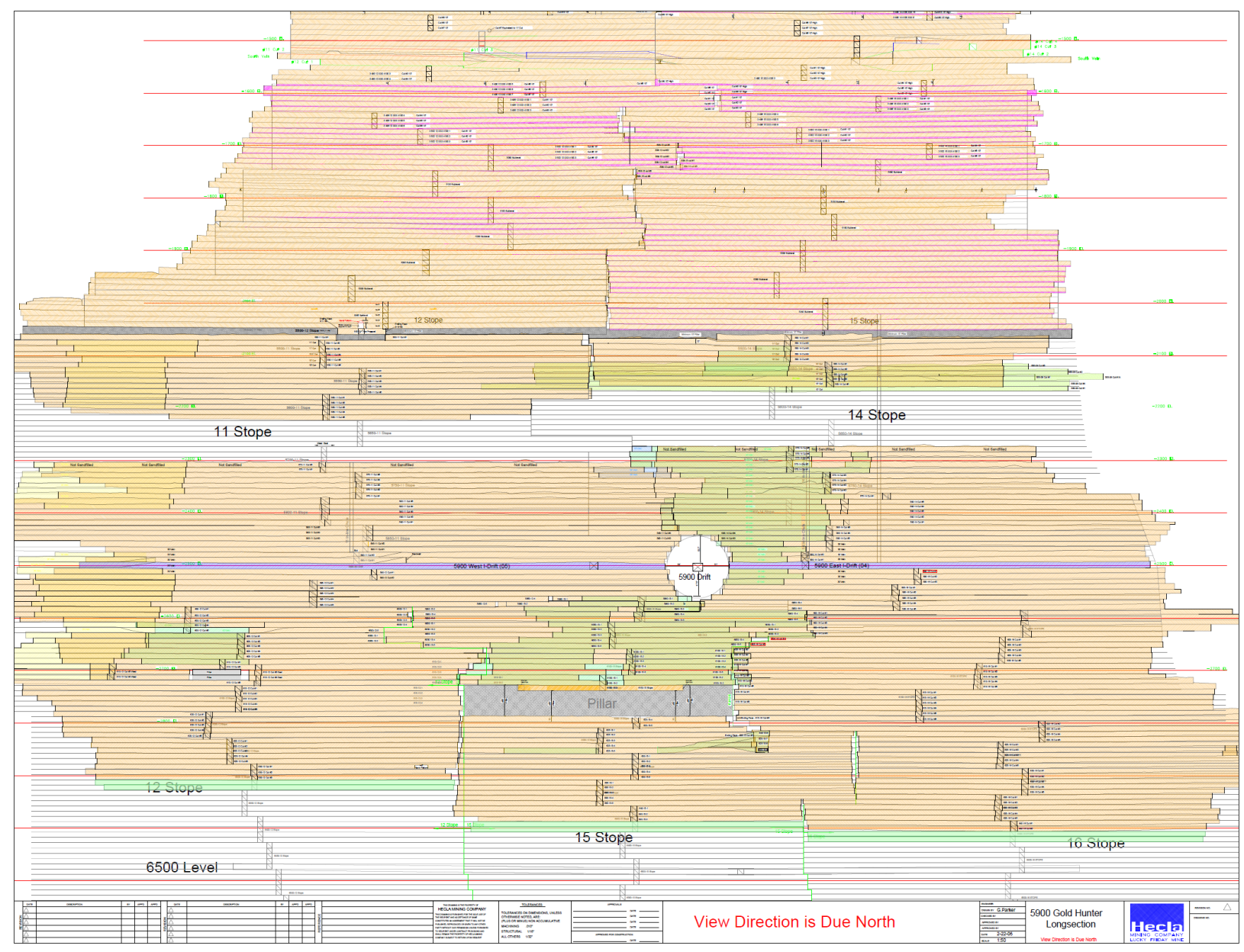

Figure 3 Longitudinal view of the Lucky Friday mine showing $3 \mathrm{~m}$ high underhand cut-and-fill stopes. The vertical depth of the 6500 level is roughly $2,300 \mathrm{~m}$ below ground surface. Tan colour are paste-filled stopes, white and grey are unmined

The host rock is a highly foliated argillite where the intact rock has an unconfined compressive strength of approximately $70 \mathrm{MPa}$, but the closely spaced talc-coated foliation $(<1 \mathrm{~cm}$ - see Figure 4$)$, which parallels the strike of the vein, results in a highly anisotropic mechanical response. The current depth of stoping is approximately $2,300 \mathrm{~m}$, with a maximum in situ horizontal stress component striking northwest with an approximate k-ratio of 1.5 .

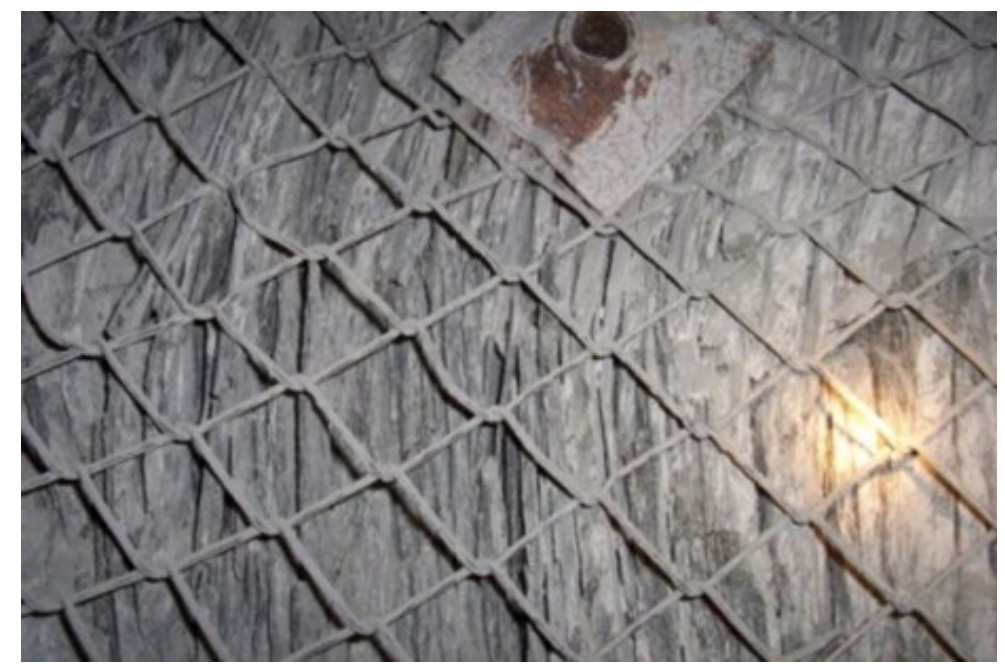

Figure 4 Heavily foliated argillite host rock at the Lucky Friday mine 
As mentioned, the host argillite responds to excavation in a highly anisotropic manner, depending on the orientation of the excavation with respect to the foliation. When excavations are driven parallel to foliation (e.g. parallel to the veins), buckling of the foliation results in large, time-dependent deformations (Figure 5). When excavations are driven perpendicular to foliation, they are generally stable with minimal support. The depth of foliation buckling into the wall rock is typically around $1 \mathrm{~m}$ but can be greater at heading intersections where there is less confinement. Typical ground support in development headings (3.65 m wide by $4 \mathrm{~m}$ high) is $1.8 \mathrm{~m}$ long friction bolts on $1 \mathrm{~m}$ centres with chain link mesh supplemented by $2.4 \mathrm{~m}$, \#7 resingrouted Dywidag bars 'five-spotted' between the friction bolts in the roof and walls. Shotcrete $(10 \mathrm{~cm}$ thickness) is used, where required, as additional surface support in combination with wire mesh. Recently, resin-grouted D-bolts have replaced Dywidags in drifts driven parallel to foliation to accommodate larger deformations and seismic loading. In drifts where excessive deformation has interfered with passage of mine equipment, the walls have typically been slabbed to widen the opening followed by new support application.

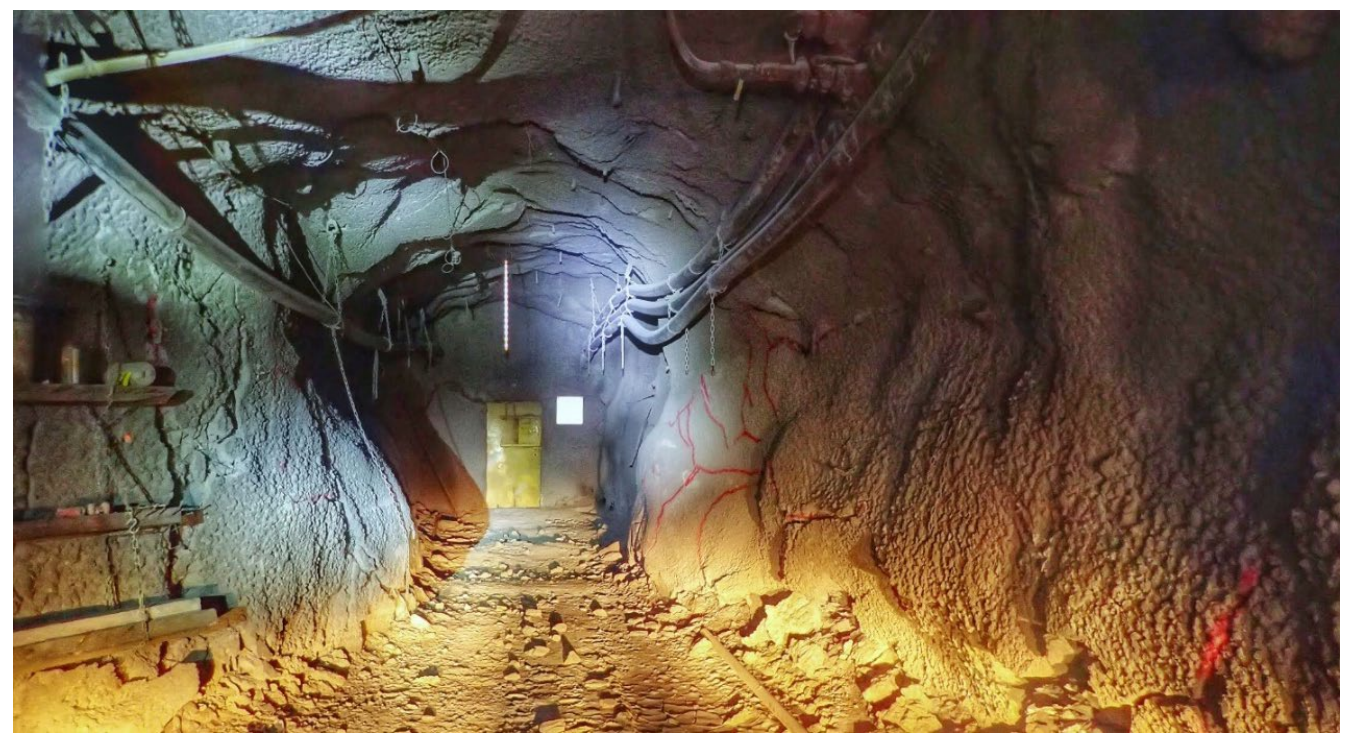

(a)

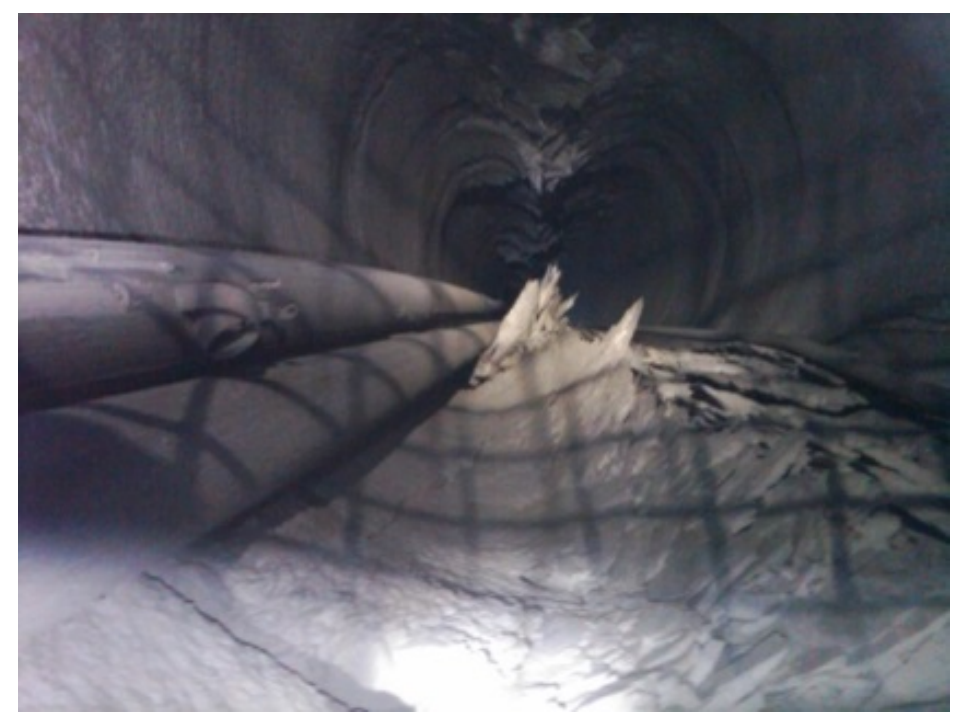

(b)

Figure 5 Typical effect of foliation on failure mechanism and large deformations at the Lucky Friday mine. (a) Drift sidewall deformation and fracturing of shotcrete; (b) Breakout in a $1.8 \mathrm{~m}$ diameter unlined raisebore. These deformations are the result of buckling of the thin foliation when excavations are driven parallel to foliation strike 


\subsubsection{Ground control issues encountered during sinking of the \#4 Shaft}

The 30 Vein continues to $>3,000 \mathrm{~m}$ in depth (ultimate depth unknown) with increasing silver and base metals grades below about 2,300 $\mathrm{m}$. The current Silver Shaft has a maximum operating depth of approximately 2,100 $\mathrm{m}$, below which spiral ramps are used to access the orebody. As a result of the continued strength of the orebody with depth, a decision was made in the late 2000s to sink a circular, $5.5 \mathrm{~m}$ finished diameter winze, collared at $1,800 \mathrm{~m}$ depth, to a total depth of $3,000 \mathrm{~m}$ to provide access to the deep ore (Strickland et al. 2016). For the initial $450 \mathrm{~m}$ of shaft construction below the collar, only minimal support was required in the form of $1.8 \mathrm{~m}$ long friction bolts on $1.5 \mathrm{~m}$ centres with chain link mesh and a nominal $30 \mathrm{~cm}$ thick, unreinforced concrete lining.

As the shaft reached the 6500 level station $(2,286 \mathrm{~m}$ below surface), minor cracking of the concrete lining appeared on the north and south walls of the shaft (locations parallel to foliation) near the shaft station. The mechanism for this cracking was assumed to be buckling of the foliation as observed in numerous raisebores at similar depth (Figure 5). The initial response to this cracking was a revision of the ground support to include grouted, $18 \mathrm{~mm}$, bulbed cables, with $6 \mathrm{~m}$ minimum embedment length, which were placed in rows spaced $1.5 \mathrm{~m}$ apart vertically. Each row consisted of five cables in the north wall and five cables in the south, spaced $1.2 \mathrm{~m}$ apart horizontally, to provide deep anchorage and to restrain the foliation buckling mechanism. This additional support, which successfully eliminated further liner cracking, was continued until the shaft was 12 $\mathrm{m}$ below the 6580 level loading pocket excavation, after which the cabling was stopped. No difficulties with ground control were noted between the cessation of cable bolting below the 6580 level and the approach to the 7500 level.

When the shaft reached the 7580 loading pocket level, extensive vertical cracking of the liner on the north shaft wall above the 7500 level was observed. Shaft ground support was increased to five $6 \mathrm{~m}$ cable bolts per row on the north and south walls spaced on a $1.2 \mathrm{~m} \times 1.2 \mathrm{~m}$ pattern, with $3.6 \mathrm{~m}$ resin-grouted \#7 Dywidags placed midway, or 'five-spotted', between them (Figure 6). Shortly after the initial cracking was observed, extensive concrete spalling and vertical fracturing of the concrete on both the north and south walls occurred from above 7500 level to the shaft bottom below 7580 level (about $25 \mathrm{~m}$ vertical distance). Despite the heavier ground support, cracking of the liner continued. The cracking and wall deformations were significant enough that future problems with guide alignment would undoubtedly occur, resulting in the need to remove the lining from 7500 level to the shaft bottom. At this point, it was necessary to determine a course of action for construction of the final $650 \mathrm{~m}$ of the shaft.

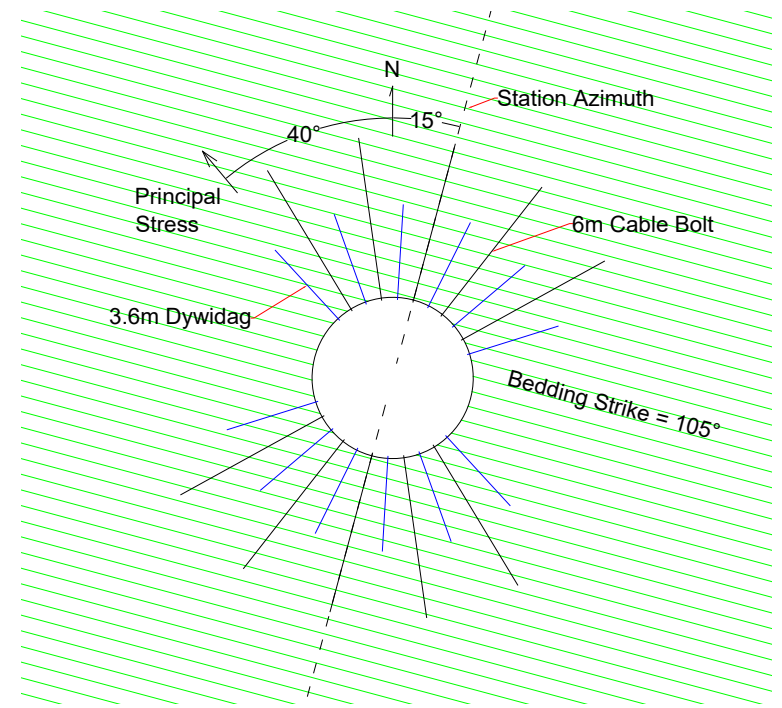

Figure 6 Additional ground support installed at 7580 level to suppress the foliation buckling. Direction of foliation shown striking at an azimuth of $105^{\circ}$ 


\subsubsection{Corporate, mine operations, and contractor jointly work towards solution}

As removal of the affected shaft liner continued, a team of corporate, mine, and contractor (Cementation, Ltd) engineers performed a risk assessment of possible paths forward to develop a stable shaft requiring no long-term intervention. Observations of the shaft wall during liner removal clearly showed the regions of foliation buckling on the north and south sides of the shaft that was the root cause of failure of the liner. Possible solutions discussed included: (a) installation of heavier or alternative forms of bolting and cabling to suppress wall deformation, (b) change in the liner design, including reinforcement of the concrete lining, higher strength concrete or thicker liner, (c) use of exotic techniques such as compacting seams in the liner to allow deformation without cracking, sliding mounts on shaft guides, etc., and (d) change of shape of the shaft cross-section to inhibit initiation of buckling.

Calculations were performed at the corporate level to examine these alternatives using two- and three-dimensional discontinuum numerical modelling with coupled ground support elements ${ }^{2}$. It was determined that there were limited options for revising/increasing the ground support to the point that the rock mass deformations could be stabilised economically. Consequently, developing new ground support or liner strategies was viewed as a last resort. Instead, greater attention was paid to the impact of an alternative cross-sectional shape of the shaft with the objective of attaining a stable state without additional ground support. The UDEC discontinuum program (Itasca 2011), shown in Figure 7, was initially used to represent the circular shaft excavation, the thin foliation orientation and the northwest-striking principal stress orientation and estimated magnitude at the 7500 level ( 2,600 $\mathrm{m}$ depth). Later, a full 3D evaluation of the geometry of the shaft, shaft stations and loading pocket was performed.

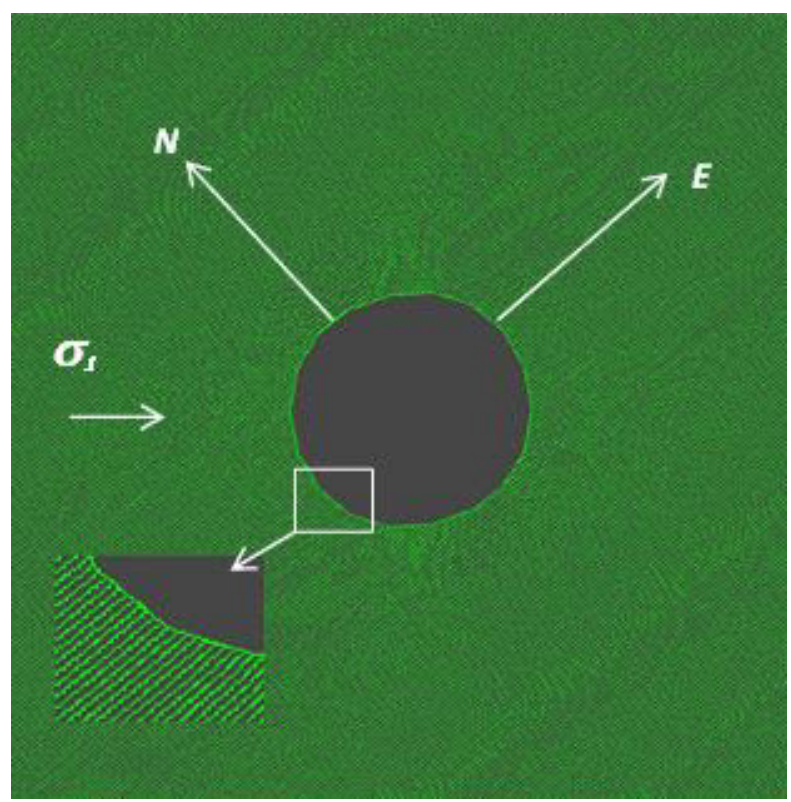

Figure 7 UDEC two-dimensional model of the circular shaft and maximum principal stress orientation. Inset shows discontinuum, platy blocks formed by foliation that are vertical in dip and strike roughly east-west

The intact rock mass was treated as a Mohr-Coulomb material characterised by a UCS of $70 \mathrm{MPa}$, and the foliation planes were assumed to be planar and have zero cohesion and $20^{\circ}$ angle of friction (resulting from the talcy coatings). The circular shaft geometry was modelled initially, indicating the observed buckling mechanism of failure where the shaft walls are parallel to the foliation strike.

The resulting wedge-shaped failure region (Figure 8) on opposing sides of the shaft was about one-half the shaft radius in depth and the model indicated unstable deformations in these areas. This modelling appeared

2 For greater detail on this modelling, see Walton et al. (2018) 
to roughly match (slightly over-predict) the field observations of breakout in the shaft wall after loosened and failed material was extracted. The conclusion from this modelling was that if the rock mass failed in this shape and to this depth, the logical approach would be to excavate the shaft to that shape initially. This concept is certainly not new, but the modelling had illustrated that the lowest risk alternative for providing a stable shaft was to excavate a roughly elliptical shape from the outset and to not attempt to provide very heavy support with little likelihood of success.

To verify this conclusion, the model was again run using a notched elliptical shape roughly equivalent to the estimated failure shape. The results (Figure 8 ) indicated that foliation shear and dilation are suppressed due to the greater confinement provided by the elliptical shape of the shaft and that equilibrium was achieved with unsupported conditions. Based on these results, it was determined that: (a) the shaft would be blasted roughly to the elliptic shape based on the modelling (Figure 9) and supported using the baseline friction bolt and Dywidag support, and (b) displacement and liner stress instrumentation would be installed for verification of rock mass and liner response for the remainder of the shaft sinking. Figure 10 shows a typical instrumented shaft section consisting of three $10 \mathrm{~m}$ long, six-anchor extensometers (Mine Design Technologies) oriented perpendicular and parallel to bedding, and tangential and radially oriented concrete pressure cells (Geokon). The pressure cells and extensometers were installed after the shaft bottom had been excavated $6.6 \mathrm{~m}$ beyond the instrument elevation (i.e. deformation had occurred due to face advance prior to installation of the instruments).

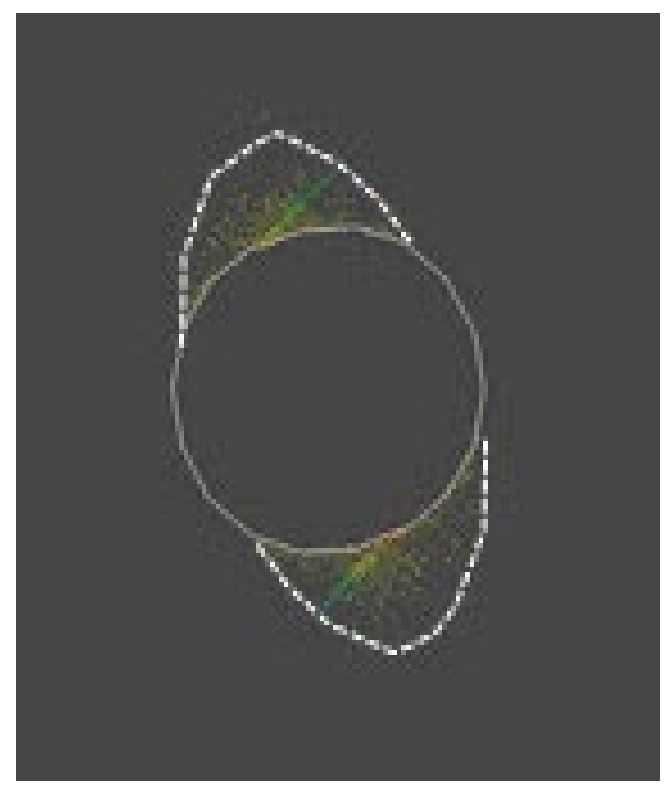

(a)

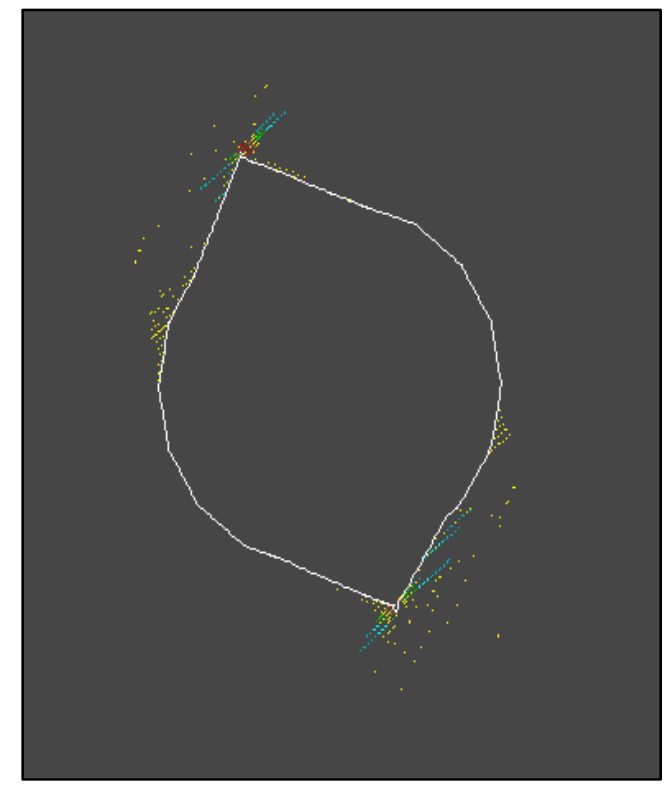

(b)

Figure 8 (a) Failure mechanism of the circular shaft showed buckling of the foliation leading to formation of a wedge-shaped failed region of dilation and shearing on the beds at the north and south sides of the shaft to a depth of nearly $1 / 2$ of the shaft radius. Excavation of an elliptical shape indicates a stable configuration is reached. (b) This plot shows dilation and shearing mechanism is suppressed due to the increased confinement to the foliation created by the notched shape 


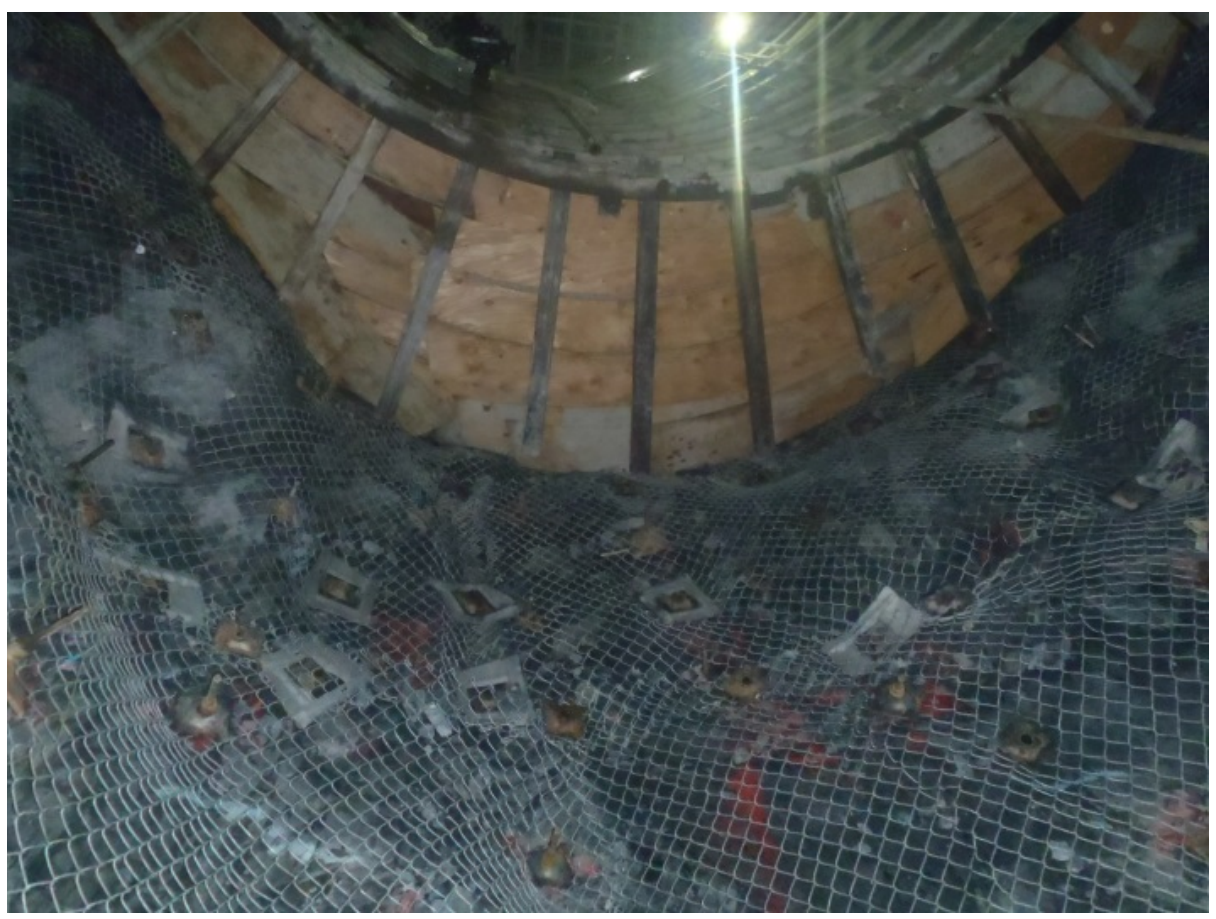

Figure 9 View up from shaft bottom showing the base of the liner after excavation of an elliptical shape for the shaft

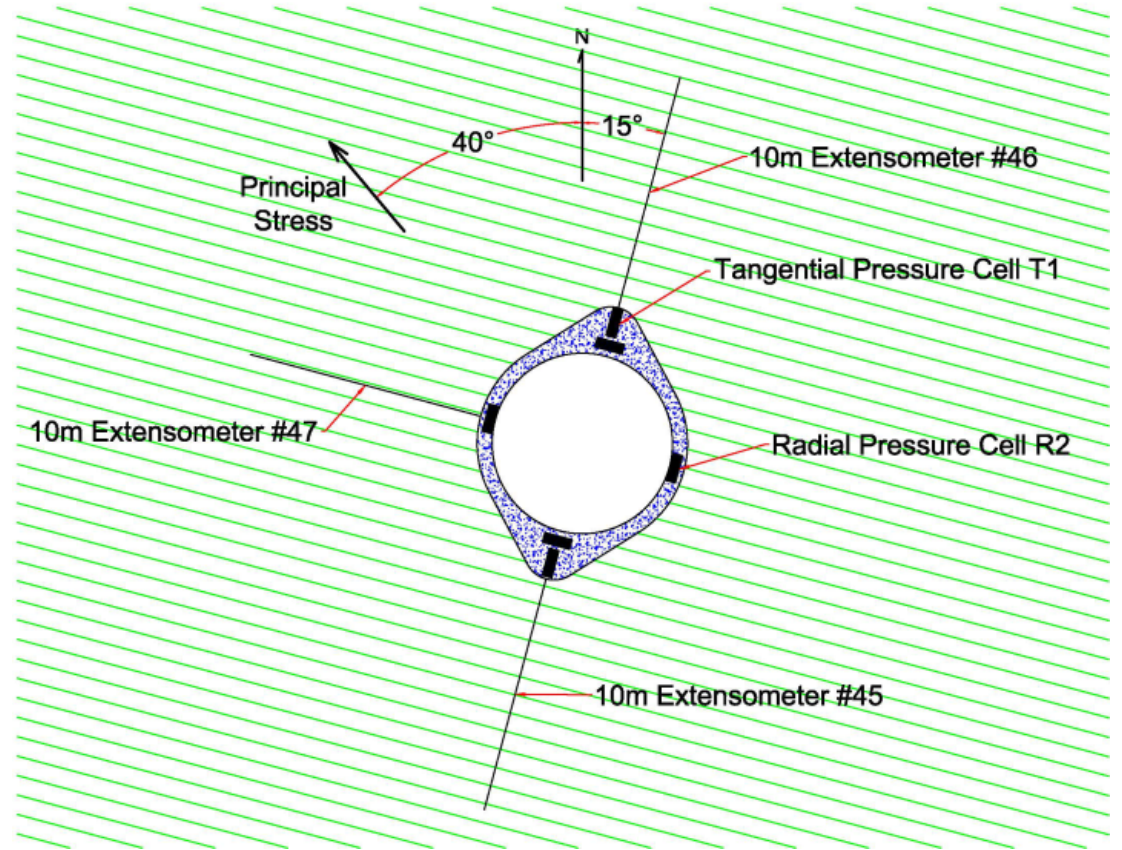

Figure 10 Typical instrumented shaft section showing three $10 \mathrm{~m}$, six-anchor rod extensometers perpendicular and parallel to foliation and tangential and radially oriented concrete pressure cells

Typical displacement results from an extensometer collared in the notch and oriented perpendicular to foliation is given in Figure 11, while sample tangential and radial stress gauge results shown in Figure 12 . The abrupt loss in data after approximately one month of recording of the extensometer was due to loss of the instrument. 


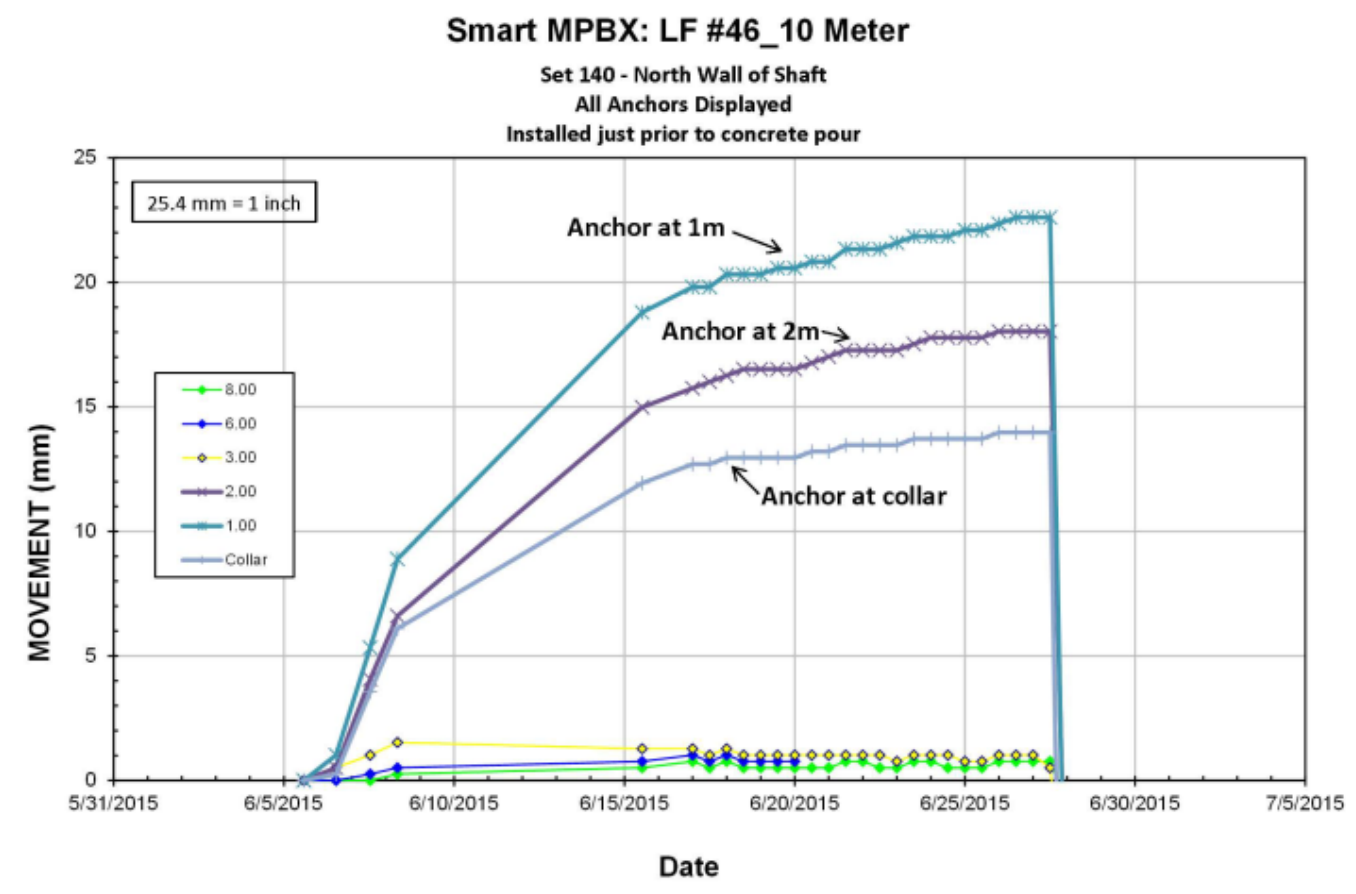

Figure 11 Extensometer displacement as a function of time for foliation-perpendicular orientation

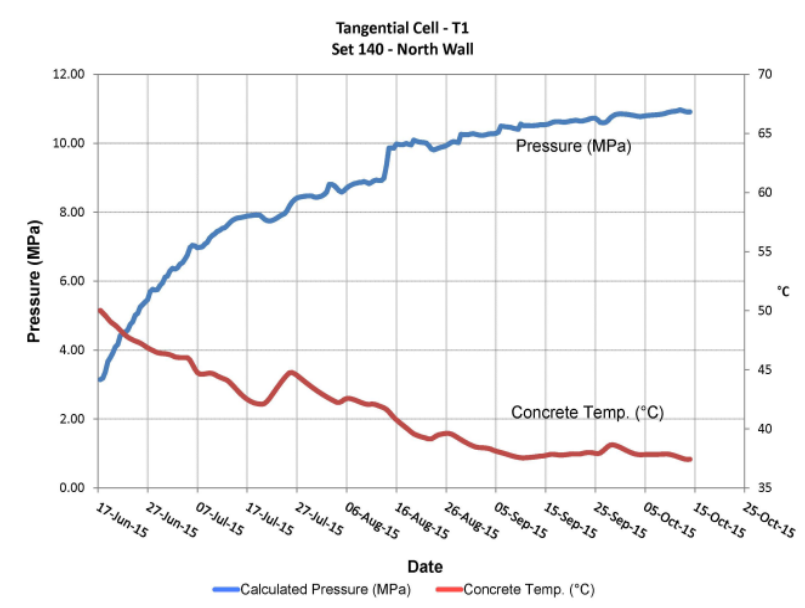

(a)

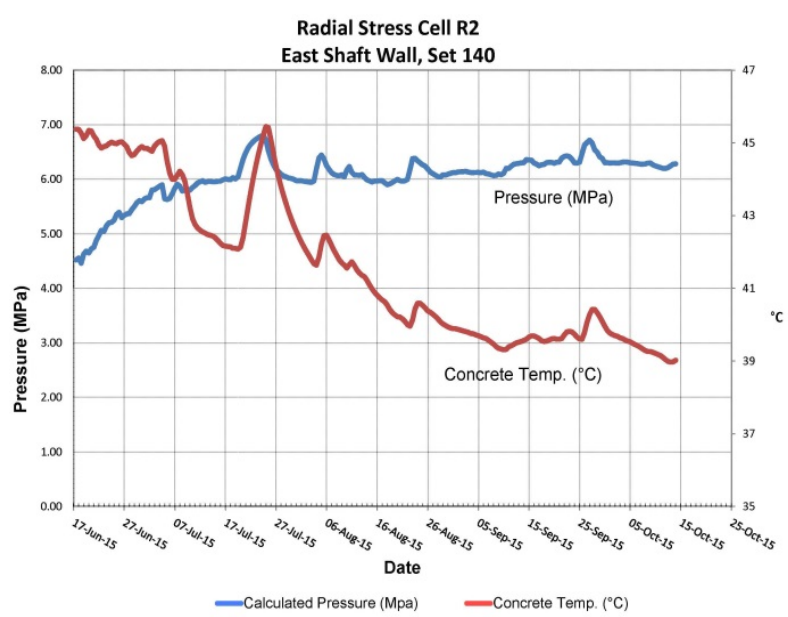

(b)

Figure 12 (a) Tangential and (b) radial concrete pressure cell measurements as a function of time

The radial displacement perpendicular to the foliation strike equilibrated at about $25 \mathrm{~mm}$ after roughly one month as the face advanced beyond the range of influence. Deformation is occurring within the first $\sim 2 \mathrm{~m}$ of the shaft wall with rapid decay thereafter. There is a small time-dependent deformation mechanism as seen (also seen on subsequent instruments), however the rate of change became insignificant with time, and has not proven to be an issue in liner loading. The tangential stress change (liner thrust direction) increased by about $10 \mathrm{MPa}$, primarily as a function of contraction as the liner cooled and time-dependent deformation occurred over several months. Curiously, the greatest radial deformation in the foliation-perpendicular direction occurred at the $1 \mathrm{~m}$ anchor depth, and not immediately at the collar of the hole (the rock surface). This observation was repeated in the other extensometers installed as the shaft was deepened. The probable explanation for this observation is shown in Figure 13 (Walton et al. 2018). Since the liner was installed $6.6 \mathrm{~m}$ behind the installation of the extensometer, the buckling mechanism, with associated foliation dilation had already begun near the shaft surface prior to liner installation. After liner installation, the liner resisted further inward surface movement of the wall. With continued radial deformation of the rock mass toward 
the shaft, the dilated foliation was compacted, resulting in larger recorded inward movement from slightly deeper in the rock mass.

The shaft was completed to the planned depth of approximately 3,000 m with no further observations of liner cracking and with equilibrating inward deformations as shown by extensometers installed at regular intervals. At the time of this writing, approximately four years after the initial observations of liner failure, the shaft has been completed and is in service with no observation of significant crack development or guide misalignment. The primary conclusion of this process is that the change of shaft shape, although resulting in $15 \%$ additional excavation, $11 \%$ additional ground support (including a $15 \%$ increase in concrete), resulted in stability of the shaft and assurance of long-term serviceability. This is particularly important considering the potential cost of continued shaft repair, production downtime, etc. The 'moral of this story' is that sometimes use of simple approaches, such as change of excavation shape, are preferable to use of ever-increasing ground support density or exotic ground support solutions for stabilising deep excavations.

\section{Immediately After Excavation \\ Before Liner Installation}

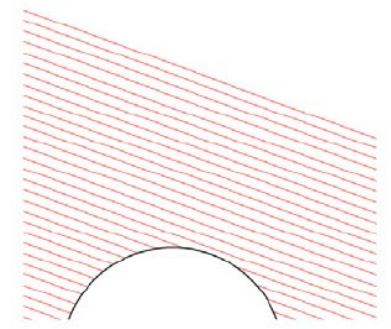

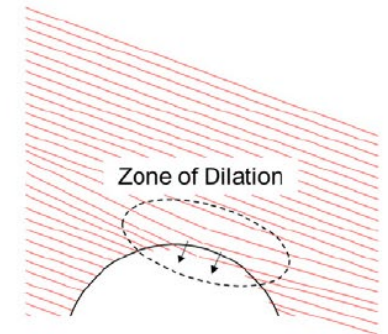

After Liner Installation

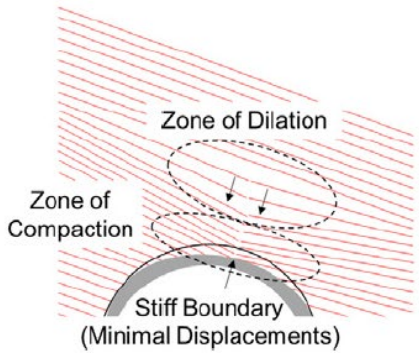

Figure 13 Radial extensometers installed perpendicular to foliation indicated that foliation dilation resulting from buckling at the shaft surface is suppressed by the shaft liner after installation, resulting in compaction of the near-shaft dilation with continued face advance (Walton et al. 2018)

\section{Summary}

The role of the company head office in ground support and general application of ground control engineering to a company's mine operations was reviewed, with reference to how this function is performed at Hecla Mining Company. It was shown that, for Hecla, one of the most important functions of corporate ground control is to provide a bridge between ground control operations at the mines and the upper management of the company who may not always understand the safety and financial implications of ground support to the health and success of the company. Additionally, the corporate office can often provide higher-level consulting assistance to the ground control functions at the mine sites where the engineers do not have the expertise or time available to perform longer-term studies, such as numerical modelling, that assist the operation. Finally, the corporate function can act to encourage interaction (cross-pollination) between engineers at the various operations, providing a healthy internal consulting practice within the company.

\section{References}

Itasca 2011, UDEC, version 5.0, computer software, Itasca Consulting Group, Minneapolis.

Walton, G, Kim, E, Sinha, S, Sturgis, G \& Berberick, D 2018, 'Investigation of shaft stability and anisotropic deformation in a deep shaft in Idaho, United States', International Journal of Rock Mechanics and Mining Sciences, vol. 105, pp. 160-171.

Strickland, B, Board, M, Sturgis, G \& Berberick, B 2016, 'Elliptical shaft excavation in response to depth induced ground pressure', Society of Mining Engineers Annual Meeting, Englewood. 
